\title{
A HOLISTIC APPROACH OF AMNESTY APPLICATION FOR BAIQ NURIL MAKNUN IN THE FRAMEWORK OF CONSTITUTIONAL LAW OF INDONESIA
}

\author{
Reda Manthovani ${ }^{1}$; Kukuh Tejomurti ${ }^{2}$ \\ ${ }^{1}$ Faculty of Law Pancasila University; ${ }^{2}$ Faculty of Law Universitas Sebelas Maret \\ Email: satryo_solo@yahoo.com; kukuhmurtifhuns@staff.uns.ac.id
}

\begin{abstract}
The Supreme Court has rejected a petition for case review from Baiq Nuril Maknun, a West Nusa Tenggara woman who was convicted of defamation against her alleged sexual harasser. Justices Margono, Desniyati and Suhadi rejected Nuril's challenge against the Supreme Court's decision in September 2018, which found Nuril guilty of violating Article 27 of the Electronic Information and Transactions (ITE) Law and sentenced her to six months in prison and a fine of Rp 500 million (US\$34,644). The defamation case has been criticized for using the controversial law to incriminate an alleged victim of sexual harassment, when the Mataram Education Agency reported Nuril for recording the phone call.This research is prescriptive normative research namely, legal research that takes legal issues as a norm system used to provide prescriptive justifications about a legal event. From Nuril's case we can see the laws are sorely inadequate, case in point the Electronic Information and Transactions Law (ITE Law), that got her into trouble. It's so rubbery, it can be interpreted any way anyone wants. Amnesty should be given to Baiq Nuril Maknun because amnesty is the authority of the President for the interests of the state, in this case human rights and citizens' rights to get legal protection and free from discrimination and Law Number $11 \mathrm{Drt}$ In 1954, yet it contradicted the constitution in cases and institutions, because Article 14 paragraph (2) of the 1945 Constitution of the Republic of Indonesia had no case restrictions in granting amnesty and was carried out with consideration of the People's Representative Council of The Republic of Indonesia.
\end{abstract}

Keywords: amnesty; interception; legal remedies

\section{INTRODUCTION}

In September 2018, Judge at the cassation level has sentenced Baiq Nuril Maknun (hereinafter: Baiq Nuril) for 6 months in prison and a fine for 500 Million Rupiah because she has violated Article 27 (1) Law number 11 of 2018 regarding Information

\footnotetext{
\begin{tabular}{ll|l}
\hline Yustisia Volume 8 Number 2 (May-August 2019) $\quad$ Holistic Approach Of Amnesty........... & $\mathbf{2 7 7}$
\end{tabular}

(C)2019; This is an Open Acces Research distributed under the term of the Creative Commons Attribution Licencee (https://Creativecommons.org/licences/by/4.0), which permits unrestricted use, distribution, and reproduction in any medium, provided the original works is properly cited.
} 
and Electronic Transaction (hereinafter: Electronic Information And Transaction Law) by recording allegations of sexual harassment by his superiors at Mataram 7 Public Senior High School (SMA N 7 Mataram) in August 2012. The Cassation Appeal results changed the decision of Mataram District Court that release Baiq Nuril. For the above decision, Baiq Nuril submits a Judicial Review (hereinafter: PK/Peninjauan Kembali) and her submission is rejected by The Supreme Court Of The Republic Of Indonesia, which means The Supreme Court Of The Republic Of Indonesia's cassation result that sentence Baiq is still applicable. Judicial review's judges asses the Baiq Nuril's case, which transmitted immoral content as regulated in Electronic Information And Transaction Law, is happened. Because this Supreme Court Of The Republic Of Indonesia's decision many parties ask President to give amnesty or abolition of punishment to Baiq Nuril.

For the information mentioned by Kompas media, Baiq Nuril is a former honorary teacher in SMAN 7 Mataram, who was a victim of sexual harassment conducted by $\mathrm{M}$ as the headmaster of the school where Baiq Nuril works. Baiq Nuril was sentenced to be guilty in Putusan Kasasi Number 574K/Pid.Sus/2018 dated 26 September 2018, for criminal act “ by distributing or transmitting immoral content" according to Article 27 (1) Electronic Information And Transaction Law and charged with 6 months in prison and a fine for 500 Million Rupiah (Kompas. "Perjalanan Panjang Baiq Nuril", Accessed on 2 August 2019). The decision has caused several protests in society because Baiq Nuril has been found guilty in cassation decision after in 2017 she has been found for not guilty in Mataram District Court Decision Number 265/Pid.Sus/2017/PN.More

The author briefly explains the chronology of Baiq Nuril's case as follows :

1. Baiq Nuril Maknun ( housewife 36 years old). Bia Nuril is an honorary teacher in SMAN 7 Mataram. However, she was later fired by M ( Headmaster of SMAN 7 Mataram) M report criminally to Baiq Nuril with the criminal accusation of defamation in Electronic Information And Transaction Law;

2. M, known to be close with Baiq Nuril and L ( treasury of SMAN 7 Mataram) because Baiq Nuril and L are often invited to work overtime in school. M often called Baiq Nuril whereas in the beginning, M talked about job issues, however, in the end, $\mathrm{M}$ started to things that lead to immoral content which are considered to be not appropriate to be done by Headmaster. In fact, Baiq Nuril is often to be seduced and invited to stay overnight in Hotel by $M$ but Baiq Nurul rejected it (Erasmus A.T. Napitupulu dan Supriyadi W. Eddyono, 2018: 9;)

In August 2012, around 16.30, Baiq Nuril received a call from M. In the conversation via call, $\mathrm{M}$ told about his affair; Baiq Nuril initiative to record his conversation with Nokia as her phone to be used as an evidence that herself did not 
have any special relationship with $\mathrm{M}$ because there was a rumor that Baiq Nuril has an affair with $\mathrm{M}$ because she often asked to work overtime with $\mathrm{M}$ and $\mathrm{L}$. Baiq Nuril also told the existence of the record between her, M and F (Kompas, "Belajar dari Kasus Baiq Nuril", https://kompas.id/baca/opini/2019/07/10/belajardari-kasus-baiq-nuril, accessed on 10 Juli 2019)

In December 2014 - January 2015, Baiq Nuril asked to return her Nokia phone to LAR (brother in law) who works in Mataram City Sanitation Department and gave it to HIM ( SMAN 7 Mataram employee). For around 2 weeks, HIM, always ask for her phone and the record. HIM eventually copy the record into his laptop. This action was conducted without Baiq Nuril's acceptance. HIM send the record to MHJ and SKR (SMAN 7 Mataram employee) and ID ( SMAN 7 Mataram advisor in Dinas Dikpora Kota Mataram)

$M$ was later dismissed from being SMAN 7 Mataram Headmaster and mutated to become Head of Non-Formal Education (PLS) in Mataram Dinas Dikpora. M dismissed Baiq Nuril. 4 days before, Baiq Nuril and Him were called by Head of Mataram Dinas Dikpora who questioning the truth of the record between $\mathrm{M}$ and Baiq Nuril.

On March 17, 2015, M officially reported Baiq Nuril to the Mataram Regional Police with Report Number LP / K / 216/2015 / Mataram Regional Police using Article 27 Paragraph (1) UU ITS of the Juncto Article 45 of the Electronic Information And Transaction Law . On March 27, 2017, Baiq Nuril was summoned by the Mataram Police Investigator and was immediately detained with a Detention Warrant Number Sprin-Han / 35 / III / 2017 / Reskrim from the Mataram Police Station on March 24, 2017, to April 15, 2017. On April 12, 2017 Detention Baiq Nuril by the Public Prosecutor at the Mataram District Attorney from 12 April 2017 to 1 May 2017. On 4 May 2017 the initial trial of the case at the Mataram District Court with the agenda of reading the Indictment Letter from the Public Prosecutor. On July 26, 2017, Baiq Nuril was declared free and was not proven to violate Article 27 Paragraph (1) of the Electronic Information and Transaction Law through Mataram District Court Decision Number 265 / Pid.Sus / 2017 / PN.Mtr. The Public Prosecutor filed an appeal to appeal to the Supreme Court. On September 26, 2018, the Supreme Court found Baiq Nuril guilty. Excerpt of Cassation Decision Number 574K / Pid.Sus / 2018 which was just received on November 9 stated that Baiq Nuril had committed a crime as regulated in Article 27 Paragraph (1) of the Electronic Information and Transaction Law by the Supreme Court. On November 16, 2018 the Defendant's summons was issued B-1109 / P.2.10 / 11/2018 to implement the Supreme Court's Decision stating that Ms. Nuril had to appear before the Public Prosecutor on November 21, 2018.

This ruling should only examine the application of the law of the courts below it so that there will be no Supreme Court decision that is more severe than the first 
tier and the appeal level. In addition, there is an allegation of the Supreme Court in making a decision not to review the Supreme Court Regulation Number 3 of 2017 concerning Guidelines for Judging Women's Cases Against the Law. The cassation verdict was seen as not fulfilling the element of justice for women's rights, so an attempt was made to review the Supreme Court against his case which later the Supreme Court rejected the PK. The Supreme Court rejected the PK request submitted by Baiq Nuril. This means that Baiq Nuril, as a convict, will carry out a six-month prison sentence and a fine of Rp. 500 million for a three-month sentence according to the Supreme Court's appeal (Shanti Dwi Kartika, 2019: 2).

Various public criticisms about the Supreme Court's PK Decision on Baiq Nuril emerged. Some said that the decision did not protect women as stated in the Supreme Court Regulation Number 3 of 2017 concerning Guidelines for Judging Women's Cases Against the Law (Sulistyowati Irianto, 2006: 28). In prosecuting women who are in conflict with the law, judges are expected to be able to identify and consider the facts of the trial in relation to social status inequality in society which results in gender inequality between women and men. Judges are also expected to be able to identify and consider power relations between parties who have litigation which results in women being powerless. Legal neutrality is considered unable to recognize women's experiences, especially protecting women's interests. The ideology of legal neutrality is not sensitive to the fact of differences in society (Anita Dhewy, 2018: 5). There was also public criticism which stated that the court knew the law, but was blind to justice. In fact, it is not uncommon for the community to judge Baiq Nuril is a victim of criminalization. A study by Sri Wiyanti Eddyono shows several important issues in current criminal law enforcement practices that fail to protect women from threats, gender-based violence, and instead become a means of controlling women's freedom and reproducing gender inequality.

With the dismissal of the PK based on decision Number 83 PK / Pid.Sus / 2019, Baiq Nuril's efforts to seek justice along the judicial route have been completed and the legal instruments that are still available on the executive track are Clemency, Abolition, Amnesty, and Rehabilitation which will be examined in this article. Based on the background that has been provided in preliminary, hence the author has formulated the problems as follow: the authors want to analyze the juridical review of the recording/tapping conducted by Baiq Nuril on the conversation between $\mathrm{M}$ and Baiq Nuril Maknun; and analyze the granting of Amnesty to Baiq Nuril is in accordance with the Law.

\section{RESEARCH METHODS}

This study is normative prescriptive which legal research that took an issue from the law as a norm system used to give a prescriptive "justification" about a

280 Yustisia Volume 8 Number 2 (May-August 2019) $\quad$ A Holistic Approach Of Amnesty ... 
legal event. Data collection is carried out through library research and field research and the library research stage is carried out to find secondary data using primary, secondary and tertiary legal materials. Some approaches used in this study are the statutory approach, the historical approach, and the conceptual approach. (Peter Mahmud Marzuki: 2005: 93-95). The results of this study will be presented in a descriptive-analytical form.

\section{RESEARCH RESULTS AND DISCUSSION}

\section{A. Illegal Conversation Recording and Distribution of Content Containing}

\section{Immoral content.}

In the above case, Baiq Nuril is accused to record a conversation through her cellphone between Muslim (Headmaster) and Baiq Nuril, and then the result of the conversation contains a story of his sexual intercourse with Baiq's friend and then given to the witnesses Imam Mudawin and after that the record was spread out and embarrassed by Muslim.

Recording conversations is a tapping, it is included in the judge's judgment in the Constitutional Court Decision Number 20 / PUU-XIV / 2016, namely: "From the provisions of article 28G paragraph (1) \& 28I paragraph (5) of the 1945 Constitution in relation with interception, this includes recording which can only be carried out according to the law. In fact, even in the context of law enforcement, the granting of tapping authority should be very limited to avoid the potential for arbitrary use of tapping ". The act of recording speech by Baiq Nuril is actually an illegal tapping action as regulated in Article 40 and Article 56 of Law Number 36 of 1999 Concerning Telecommunications and Article 31 and Article 47 of Law Number 11 Of 2008 Concerning Information and Electronic Transactions. In addition, Baiq Nuril Maknun's actions were also allegedly violating Article 27 paragraph (1) of Law Number11 / 2008 concerning Information and Electronic Transaction stated that "Everyone intentionally and without the right to distribute and/or transmit and/or make accessible electronic information and/or electronic documents that have contents that violate decency", as the Cassation decision in the Supreme Court. Because of Cassation decision and Judicial Review, The Supreme Court of The Republic of Indonesia was criticized several parties in society. In fact, a few societal organizations ask President Joko Widodo to give amnesty to Baiq Nuril which considered as a victim of "rubber" article of Electronic Information And Transaction Law. The victim of this rubber article is not the first to be happened (Hukum Online,

"Hikmah Kasus Baiq Nuril, Momen Tepat revisi UU UTE",. https://www.hukumonline.com/berita/baca/ 1 lt5d3af0b0580b9/hikmah-kasus-baiqnuril--momen-tepat-revisi-uu-ite/, accessed 
on 07 August 2019). Previously, Prita Mulyasari ( hospital patient of private hospital in Tangerang) obtain a criminal penalty because she was complaining hospital services through electronic mail to some of her friends. Prita Mulyasari was given the penalty since 1 Of of Electronic Information And Transaction Law enforced. The application of this "rubber" article of Electronic Information And Transaction Law has caused a necessity to review of Electronic Information And Transaction Law (Brave A. Sugiarto, et all, 2015: 53). The granting of Amnesty to the victim of Electronic Information And Transaction Law is not enough because the main issue is inside the Electronic Information And Transaction Law itself.

On the other hand, Baiq Nuril's position here is actually as a victim of harassment committed by the Headmaster, who in fact is his boss. The Headmaster's actions should have been punished criminal, but the Headmaster took the moment in advance by reporting Baiq Nuril's actions to the authorities. Even though the handling of the Baiq Nuril case is full of objections from various human rights activists, this case continues until the cassation decision in the Supreme Court. Because Law Enforcement Officials in this matter: Investigators, Public Prosecutors and Judges are in a pretty difficult position if the report from the Principal is not followed up, bearing in mind that the actions committed by Baiq Nuril have fulfilled the criminal elements stipulated in the Electronic Information And Transaction Law. This can be seen from the Panel of Judges' consideration that the purpose of the Electronic Information And Transaction Law is that it is expected that the use of technology and information can be carried out safely to prevent abuse by paying attention to the religious, social and cultural values of the Indonesian people, because it cannot it is undeniable that technology is now a doubleedged sword, because in addition to contributing to the improvement of the welfare and progress of human civilization, it is also the most effective media or means to carry out acts against the law (Suyanto Sidik, 2013: 3).

Supreme Court issued Supreme Court Regulation Number 3 of 2017 so the judges will be able to establish equality and remove discrimination against women. Legal protection to Baiq Nuril can be manifested if the Judge understands the position of sexual harassment victim hence the phrase "without right" provided in Article 27 (1) Electronic Information And Transaction Law is not qualified for Baiq Nuril who has recorded and given it to another party for evidentiary purposes.

If it is carefully observed that clause of Article 27 (3) Electronic Information And Transaction Law, there are three deviations that can cause, the provisions do not qualify as clear provisions for the legal content. ( non lex certa). The phrase “ without right" is not in accordance with the next sentence " containing defamation 
". That how is it possible that a person can still be given the opportunity in the form of rights so that he can distribute electronic information when the act (defamation) is actually prohibited. It is impossible for people to be entitled to the realization of an act whose form is a crime. And it is also not possible forbidden to transmit electronic information if the contents are mediocre, without defaming someone's good name.

Criminal conviction in case of a quo is expected to be a learning to the accused and to Indonesian people in general, to be more careful in exploit and using electronic media, especially related to someone's privacy data or recording/ tapping between individual, whereas the utilization and use should be done with the approval of related individual.

Recording cannot be separated from technology, which is technology in the field of telecommunications. Communication technology is indeed growing rapidly, one of which is now widely used is a mobile phone (cellphone). Certain elements of mobile phones are used as effective tools for wiretapping purposes.

Tapping by the police or prosecutors is one of the legal proofs used in legal cases (Lilis Hartini, 2010: 22). Although the recording of the tapping results is quite effective as legal evidence, there are some legal experts who disagree about the procedure for recording/tapping. The reason is that citizens' privacy is disturbed by the state. Although wrapped up in law enforcement efforts, Wahyudi Djafar had filed an application for testing Article 31 paragraph (4) of the Electronic Information and Transaction Law to the Constitutional Court on February 22, 2010 which later the Constitutional Court revoked Article 31 paragraph (4) of Electronic Information and Transaction Law.The Court emphasized that the Government and Parliament to immediately ratify the laws governing the recording/tapping in particular that guarantees the protection of privacy rights (Lilis Hartini, 2010: 2). The definition and the scope of privacy concept that often being a reference is a formulation developed by William Posser, by referring to at least four of interference of a person, as follows (William Prosser, 1984: 167) :

a. interference with one's actions to alienate or be alone, or interference with his personal relationships;

b. public embarrassing disclosure of personal facts;

c. the publicity that puts someone wrong in public;

d. unlicensed control over someone's likeness for the benefit of others;

In Indonesia, several laws and regulations provide an entry point for state officials to conduct wiretapping practices against citizens (Whitfield Diffie, 1998: 105). The absence of a legal entity that regulates this matter has created vulnerability from acts of abuse of authority committed by state officials (Wahyudi Djafar, Protecting privacy rights from wiretapping, The Jakarta Post, 
21 February 2013, accessible at http://www.thejakartapost.com/news/2013/02/21/ protecting-privacy-rights-wiretapping.html, accessed on 20 July 2019). Apart from government agencies, interference with privacy is also very likely to occur between individuals or between private bodies, for example, the practice of wiretapping is done by individuals with one another. Whereas the practice of tapping carried out by government agencies is carried out for two purposes, namely law enforcement and the implementation of intelligence functions (Kukuh Tejomurti, 2017: 68).

\section{B. An instrument of Clemency, Abolition, Amnesty, and Rehabilitation of Baiq Nuril}

With the dismissal of the PK based on decision Number 83 PK/Pid.Sus / 2019, Baiq Nuril's efforts to seek justice on the judicial route have been completed and the legal instruments that are still available on the executive track are Clemency, Abolition, Amnesty, and Rehabilitation.

Granting Clemency, Abolition, Amnesty and Rehabilitation are the authority of the President by taking into consideration the Supreme Court $(M A)$ or the People's Representative Council (DPR) as stipulated in Article 14 of the 1945 Constitution

Based on the provisions of the 1945 Constitution and various other laws and regulations, the legal terminology can be explained as follows:

1. Clemency

According to Article 1 (1) of Law number 22 of 2002 concerning Clemency, Clemency is forgiveness in the form of an amendment, mitigation, reduction, or elimination of criminal acts to convicts given by the President.

In other words, someone who got clemency from President is someone who found guilty but seeks forgiveness to the President. The criminal act or mistake of that person is not gone however the execution such as imprisonment is forgiven. Clemency should be submitted by defendant to the President and criminal verdict that can be submitted are death penalty, life imprisonment, imprisonment at least 2 years.

The issuance of clemency by the President to the defendant generally motivated by as follows (Chaerul Risal, 2017: 99):

1) If it is assessed that there is a lack of eligibility in the application of the law, then the granting of clemency, in this case, is to improve the application of the law;

2) If it is seen that the convicts are urgently needed by the state or there is a very deep regret, in this case, the granting of pardons is in the interest of the state; 
Consideration of clemency to the convicted person focuses on reassessing the judge's decision. The verdict is re-evaluated whether the decision has been in accordance with the guilt proven by the convicted person or whether the decision was found to be too heavy compared to the conditions or situation at the time of the judge's decision for reasons that are known after the judge handed down the verdict.

2. Abolition

In Emergency Law Number 11 of 1954 concerning Amnesty and Abolition, provide a definition that abolition is the legal process of someone who is on process. The granting of abolition, the prosecution of people who were given abolition was abolished

In granting amnesty and abolition, the President must also consider the consideration of the House of Representatives (Article 14 paragraph [2] of the 1945 Constitution). The granting of abolition and amnesty was also regulated in the Provisional Constitution of the Republic of Indonesia in 1950. Abolition can only be granted by law or by law, by the President after asking for advice from the Supreme Court through the Minister of Justice and Human Rights

3. Amnesty

Amnesty is regulated in Emergency Law Number 11 of 1954 on The Amnesty and Abolition, however, the said Law did not provide a certain legal definition regarding Amnesty and Abolition. However, in Article 4 it is mentioned that by giving an amnesty all the effect of criminal law against the defendant will be abolished.

President on behalf state necessary is able to give amnesty to people who committed a criminal act. President granting an amnesty after receiving a bit of advice from the Supreme Court through the Minister of Justice and Human Rights

4. Rehabilitation

Rehabilitation is an act of the President in order to restore the rights of someone who has been lost due to a judge's decision which turned out in the next time proved that a mistake made by a suspect is nothing compared to the original estimate or even he was found not guilty at all.

The focus of this rehabilitation lies in the value of honor that was regained and this does not depend on the law, but on the views of the surrounding community. Therefore, rehabilitation as referred to in Article 14 paragraph (1) of the 1945 Constitution, shall be carried out in its ability, position, and dignity, and returned to its position. 
THE DIFFERENCE BETWEEN CLEMENCY, AMNESTY, ABOLITION, AND REHABILITATION

\begin{tabular}{|c|c|c|c|c|}
\hline & Clemency & Amnesty & Abolition & Rehabilitation \\
\hline : & $\begin{array}{l}\text { change, mitigation, } \\
\mathrm{r} \text { e d u c } \mathrm{t} \text { i o } \mathrm{n} \text { or } \\
\text { elimination of the } \\
\text { implementation of } \\
\text { the criminal to the } \\
\text { defendant }\end{array}$ & $\begin{array}{l}\text { forgiveness or } \\
\text { abolition of the } \\
\text { punishment given } \\
\text { by the President }\end{array}$ & $\begin{array}{l}\text { abolition of the } \\
\text { legal process some- } \\
\text { one }\end{array}$ & $\begin{array}{l}\text { restoring the right } \\
\text { of a person who has } \\
\text { been lost because of } \\
\text { a judge's decision }\end{array}$ \\
\hline 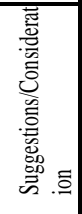 & \begin{tabular}{|l|} 
Supreme Court \\
\end{tabular} & $\begin{array}{l}\text { House of Repre- } \\
\text { sentatives }\end{array}$ & $\begin{array}{l}\text { House of Repre- } \\
\text { sentatives }\end{array}$ & Supreme Court \\
\hline 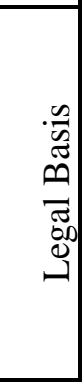 & \begin{tabular}{|l|} 
Article 14 \\
of th e 1945 \\
Constitution \\
Law Number \\
22/2002 Jo Law \\
Number $5 / 2010$ \\
c o n c e r n i n g \\
Clemency
\end{tabular} & 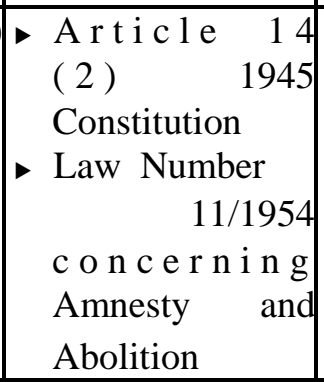 & 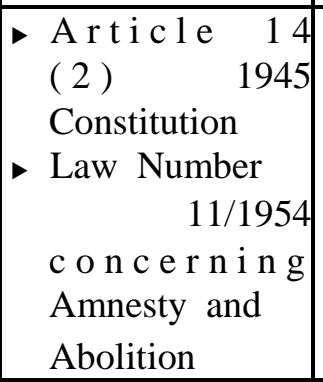 & $\begin{array}{l}\text { Article } 14 \\
\text { of the } 1945 \\
\text { Constitution }\end{array}$ \\
\hline $\begin{array}{l}0 \\
\frac{3}{0} \\
\stackrel{3}{0} \\
0\end{array}$ & $\begin{array}{l}\text { Death Penalty } \\
\text { Life imprison- } \\
\text { ment } \\
\text { Imprisonment at } \\
\text { least } 2 \text { years }\end{array}$ & $\begin{array}{l}\text { All types of } \\
\text { punishment; } \\
\text { A n y pe r s o n } \\
\text { who commits a } \\
\text { crime, before } 27 \\
\text { December } 1949\end{array}$ & \begin{tabular}{|l|} 
All types of \\
punishment \\
Any person \\
who commits a \\
crime, before 27 \\
December 1949 \\
\end{tabular} & $\begin{array}{l}\text { - Punishment does } \\
\text { not match with } \\
\text { his mistakes } \\
\text { - Criminal action } \\
\text { is not proven }\end{array}$ \\
\hline 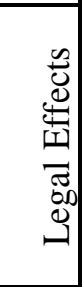 & $\begin{array}{l}\text { Alleviation } \\
\text { Reduction in } \\
\text { the number of } \\
\text { crimes } \\
\text { Abolition of } \\
\text { criminal conduct }\end{array}$ & $\begin{array}{l}\text { The result of the } \\
\text { law is abolished }\end{array}$ & $\begin{array}{l}\text { Prosecution is } \\
\text { abandoned }\end{array}$ & $\begin{array}{l}\text { R e c o v e r y of } \\
\text { ability, position, } \\
\text { and dignity, }\end{array}$ \\
\hline
\end{tabular}




\section{Is Amnesty for Baiq Nuril Maknun appropriate?}

Baiq Nuril cannot be forgiven in the form of clemency. This is because the convicting verdict handed down by the Supreme Court to Baiq Nuril is only 6 (six) months in prison, while the terms of a conviction that can be granted clemency according to the law must be in the form of capital punishment, life imprisonment, or the lowest prison sentence 2 (two years.

Then referring to Article 4 of the Emergency Law Number 11 of 1954 concerning Amnesty and Abolition stipulates that "by granting abolition, prosecution of persons referred to in Articles 1 and 2 is eliminated". With the aim of distinguishing it from amnesty, the Law a quo provides a limitation, namely "by granting amnesty, all effects on the people concerned are abolished and by granting abolition, prosecution of these persons is nullified". While the definition of prosecution according to Article 1 (7) of the Criminal Procedure Code is "Prosecution is an act of the Public Prosecutor (PU) to submit a criminal case to the competent District Court in terms of and in the manner stipulated in the law with a request that it be examined and decided by a judge in a court session.".

In relation with the a quo Law, the granting of abolition to Baiq Nuril is inappropriate. This is considering the case handling has been completed up to the Cassation stage.

Amnesty should be given to Baiq Nuril Maknun because firstly, amnesty is the authority of the President for the interests of the state, in this case, human rights and the rights of citizens to obtain legal protection and freedom from discrimination. Secondly, Law Number 11 Drt In 1954 it contradicted the constitution in cases and institutions because Article 14 paragraph (2) of the 1945 Constitution had no restrictions in granting amnesty and was carried out with consideration of the DPR RI. Third, Indonesia should commit to the elimination of discrimination and the fulfillment of women's rights because it ratifies CEDAW. On that basis, DPR RI in carrying out its supervisory function needs to immediately give philosophical, juridical and sociological considerations to the President for granting amnesty to Baiq Nuril Maknun. In addition, in the context of implementing the legislative function of DPR RI it is necessary to immediately replace Law Number 11 Drt In 1954, finalizing the Bill on the Elimination of Sexual Violence, and evaluating Electronic Information And Transaction Law.

Amnesty, in this case, should also examine the human aspect and human rights. Baiq Nuril's case is full of immoral content and sexual harassment not only physically but also verbally, hence it is potential to discriminate against women before the law. This matter is contradicted with the principles of CEDAW (Convention on the Elimination of all forms of discrimination against women)that 
has been ratified by Law number 7 of 1984, therefore Indonesia is committed to eliminating discrimination against women and women rights fulfillment (Shanti Dwi Kartika, 2019: 4). Meanwhile, Supreme Court also issued Supreme Court Regulation Number 3 of 2017 so the judges will be able to create equality and eliminate discrimination against women before the law. Legal protection can be implemented if the judge understands the position of sexual harassment victim so the phrase of "without right" stated in Article 27(1) Electronic Information And Transaction Law is not qualified for Baiq Nuril who has recorded and gave it to another party for evidentiary purposes.

If it is carefully observed that clause of Article 27 (3) Electronic Information And Transaction Law, there are three deviations that can cause, the provisions do not qualify as clear provisions for the legal content. ( non lex certa). The phrase " without right" is not in accordance with the next sentence " containing defamation ". That how is it possible that a person can still be given the opportunity in the form of rights so that he can distribute electronic information when the act (defamation) is actually prohibited. It is impossible for people to be entitled to the realization of an act whose form is a crime. And it is also not possible forbidden to transmit electronic information if the contents are mediocre, without defaming someone's good name.

The granting of formal legal amnesty on the constitutional basis there is no limitation and criteria for certain criminal cases. During this time, there are limitations to the granting of amnesty because the existing laws and regulations still determine so. However, it is no longer relevant to the current conditions. Amnesty that so far has been granted in thecase first, political crimes still use the legal basis of Law Number 11 Drt of 1954 based on Article 107 of the 1950 Temporary Constitution of The Republic of Indonesia (Seno Wibowo Gumbira, 2018: 102) and motivated by a political dispute that occurred before 27 December 1949, secondly, violations of human rights using Law Number 27 of 2004 on the Truth and Reconciliation Commission null and void by law with Constitutional Court Decision Number 006 / PUU IV / 2006, and up to now there is no substitute law governing that, and thirdly, taxation on the basis of Law Number 11 of 2016 concerning Tax Amnesty which is limited to the last fiscal Of of 2015 as specified in Article 1 number 15 of this law.

Therefore, the granting of Amnesty for Baiq Nuril by is appropriate and in accordance with statutory regulations with consideration of granting this amnesty is in the name of humanity and the interests of the State to protect victims of sexual violence in Indonesia. 


\section{CONCLUSION}

1. Based on Decision Number 574 K / Pid.Sus / 2018, the act of recording the conversation by Baiq Nuril is actually an illegal tapping act as regulated in Article 40 and Article 56 of Law Number 36 of 1999 Concerning Telecommunications and Article 31 and Article 47 of the Law Number 11 of 2008 concerning Information and Electronic Transactions. In addition, Baiq Nuril Maknun's actions were also allegedly violating Article 27 paragraph (1) of Law Number

11 of 2008 Regarding Information and Electronic Transactions. The Supreme Court issues Supreme Court Regulation Number 3 of 2017 so that judges can create equality and eliminate discrimination against women before the law. Legal protection for Baiq Nuril can be realized if the judge can understand the position of victims of sexual harassment so that the phrase "without rights" in the elements of Article 27 paragraph (1) of the Electronic Information and Transaction Law is not fulfilled for Baiq Nuril who has recorded and provided it to other parties for evidentiary purposes.

2. Amnesty should be given to Baiq Nuril Maknun because firstly, amnesty is the authority of the President for the interests of the state, in this case, human rights and the rights of citizens to obtain legal protection and freedom from discrimination. Secondly, Law Number 11 Drt In 1954 it contradicted the constitution in cases and institutions because Article 14 paragraph (2) of the 1945 Constitution had no case restrictions in granting amnesty and was carried out with consideration of the DPR RI. Third, Indonesia must commit to the elimination of discrimination and the fulfillment of women's rights because it ratifies CEDAW. On that basis, the DPR RI in carrying out its supervisory function needs to immediately give philosophical, juridical and sociological considerations to the President to grant amnesty to Baiq Nuril Maknun. In addition, in the context of implementing the legislative function of the Indonesian Parliament it is necessary to immediately replace Law Number $11 \mathrm{Drt}$ In 1954, finalized the Bill on the Elimination of

Sexual Violence, and evaluated the Electronic Information And Transaction Law. 


\section{BIBLIOGRAPHY:}

\section{Books:}

Azriana. (2019). Surat Rekomendasi Komnas Perempuan untuk Amnesti bagi Kasus Baiq Nuril, Jakarta: Komnas Perempuan

Erasmus A.T. Napitupulu dan Supriyadi W. Eddyono. (2018). Korban Pelecehan Yang Menjadi Tersangka Pasal 27 Ayat (1) ELECTRONIC INFORMATION AND TRANSACTION LAW. Jakarta: ICJR.

Irianto, Sulistyowati. (2006). Perempuan dan Hukum:Menuju Hukum yang Berperspektif Kesetaraan dan Keadilan. Jakarta: Yayasan Obor Indonesia

Whitfield Diffie,et all. (1998). Privacy on the Line: The Politics of Wiretapping and Encryption. Massetachusetts: The MIT Press,

William Prosser. (1984). Privacy: A Legal Analysis, in Ferdinand D. Schoeman (ed.). (1984). Philosophical Dimensions of Privacy: An Antology. Cambridge: Cambridge University Press.

\section{Journals:}

Dhewy, Anita. (2018). Hukum Pidana dan Ketimpangan gender. Jurnal Perempuan Volume 23 Number 2

Brave A. Sugiarto, Arie S.M. Lumenta, Dringhuzen J. Mamahit. (2012). Internet Cerdas dan Jerat Undang-Undang Informasi dan Transkasi Elektronik. Jurnal Teknik Elektro dan Komputer Volume 6 Number 3

Risal, Chaerul. (2017). Eksistensi Grasi Menurut Perspektif Hukum Pidana, Jurnal Jurisprudentie Volume 4 Number 2

Kukuh Tejomurti. (2017). The Personal Electronic Data Security on The Implementation of Solo Smart City According to The Perpective of Privacy Protection Law. Journal of Law, Policy, and Globalization, Volume 66 (2017). See https://iiste.org/Journals/index.php/JLPG/issue/view/3228

Hartini, Lilis. (2010). Kajian Linguistik Forensik Terhadap Percakapan Antara Artalyta Suryani Dengan Jaksa Urip Tri Gunawan. Jurnal Wawasan Hukum Volume 23 Number 02

Kartika, Shanti Dwi. (2019). Amnesti Bagi Baiq Nuril Maknun, Layakkah diberikan?. Info Singkat: Kajian Singkat Terhadap Isu Aktual dan Strategis, Volume XI, Number 14 (Juli 2019),

Eddyono, Sri Wiyanti. (2018). RUU Hukum Pidana dan Perlindungan Bagi Korban Kekerasan Berbasis Gender, Jurnal Perempuan, Volume 23 Number 2

$290 \quad$ Yustisia Volume 8 Number 2 (May-August 2019) $\quad$ A Holistic Approach Of Amnesty ... 
Seno Wibowo Gumbira. (2018). The Implications Of Expanding The Authority Of The Pretrial Post-Verdict Judicial Review Of The Constitutional Court In Deciding Whether It Is A Valid Determination Of The Suspect Against Law Enforcement And The Protection Of The Rights Of The Suspect. Yustisia Jurnal Hukum, Volume 7 Number 1

Sidik, Suyanto. (2013). Dampak Undang-Undang Informasi dan Transaksi Elektronik Terhadap Perubahan Hukum dan Sosial Dalam Masyarakat, Jurnal Ilmiah Widya Volume 1 Number 1

\section{Websites:}

Kompas. "Perjalanan Panjang Baiq Nuril", 2 Agustus 2019, https://regional.kompas. com/read/2019/07/09/07524561/perjalananpanjang-baiq-nuril-mencari-keadilan?page=all, accessed on 2 August 2019

Kompas, "Belajar dari Kasus Baiq Nuril”, https://kompas.id/baca/opini/2019/07/10/ belajar-dari-kasus-baiq-nuril, accessed on 10th July 2019

Hukum Online, "Hikmah Kasus Baiq Nuril, Momen Tepat revisi UU UTE”, 07 Agustus 2019. https://www.hukumonline.com/berita/baca/lt5d3af0b0580b9/ hikmah-kasus-baiq-nuril--momen-tepat-revisi-uu-ite/

Wahyudi Djafar, "Memerhatikan Perlindungan Hak Atas Privasi Dalam Pengaturan dan Praktik Penyadapan di Indonesia", http:// a d v o k a s i . e 1 s a m . or. id / a s s e t s/2015/09/2014_E L S A M _ W D _ PerlindunganPrivasiPengaturanPratikPenyadapan.pdf, accessed on 30th July 2019

Wahyudi Djafar, Protecting privacy rights from wiretapping, The Jakarta Post, 21 Februari 2013, accessible at http://www.thejakartapost.com/news/2013/02/21/ protecting-privacy-rights-wiretapping.html. 